\title{
Ecological and Structural Characteristics of Riparian Forest in Omo Biosphere Reserve
}

\author{
${ }^{* 1}$ OLATIDOYE, OR; ${ }^{1}$ OYELOWO, OJ; ${ }^{1}$ AKINYEMI, OD; ${ }^{2}$ KAMBAI, C; \\ ${ }^{1}$ AYODELE, AA \\ ${ }^{1}$ Forestry Research Institute of Nigeria, Ibadan, Nigeria \\ ${ }^{2}$ Federal College of Forestry, Jos, Nigeria \\ *Corresponding Author Email: olaremiolatidoye@gmail.com
}

\begin{abstract}
An investigation on the structural characteristics of the riparian forest in Omo Biosphere Reserve was carried out. The structure was analyzed through diameter class distribution, basal area and breast height. Riparian forest showed a major characteristic in the physiognomy of forests along major river, streams and Upland vegetation and the Core, Buffer and Transition zones that is highly variable in the diameter class distribution (reserve $\mathrm{J}$ type), Mean basal area per hectare for major river is $294,089.30 \mathrm{~cm}^{2} /$ ha, Stream $613.027 \mathrm{~cm}^{2} / \mathrm{ha}$, and Upland $205,648 \mathrm{~cm}^{3} / \mathrm{ha}$. Mean basal area for core is $507,399.50 \mathrm{~cm}^{2} / \mathrm{ha}$, buffer had $340,699 \mathrm{~cm}^{2} /$ ha and transition $264,656 \mathrm{~cm}^{2} / \mathrm{ha}$. While mean volume per hectare for core is $7955.2 \mathrm{~m}^{3} / \mathrm{ha}$, buffer $7260 \mathrm{~m}^{3} / \mathrm{ha}$ and Transition $6254.4 \mathrm{~m}^{3} / \mathrm{ha}$. Maximum dbh of $246 \mathrm{~cm}$ was obtained in the core species. Many stands of riparian forests are facing various levels of structural and floristic simplification, which include fundamental transformations in vegetation physiognomy from dense stands to riparian scrub or bare land.
\end{abstract}

DOI: https://dx.doi.org/10.4314/jasem.v24i9.28

Copyright: Copyright (C) 2020 Olatidoye et al. This is an open access article distributed under the Creative Commons Attribution License (CCL), which permits unrestricted use, distribution, and reproduction in any medium, provided the original work is properly cited.

Dates: Received: 10 August 2020; Revised: 16 September 2020; Accepted: 22 September 2020

Keyword: Riparian forests, structure, diameter, basal area, species dominance, Omo

The most paramount danger to the world's biological diversity is the fragmentation and forfeit of tr opical forest, and this is a key research topic in landscape ecology (Wu, 2013). The Convention on Biological Diversity pointed out that measures must be implemented for the conservation of natural ecosystems, especially for tropical forests, which are famous for being the most species-rich ecosystems on earth. Understanding the consequences of fragmentation in our habitat structure is essential to the functioning of ecosystem and biodiversity preservation. Disruption of watershed vegetation, damming of water courses and diversion of stream flow, excessive lowering of aquifer levels through pumping, channelization and levee construction on water courses often cause significant damage to riparian systems. As a result, indigenous multi-layered plant communities have been completely removed in many parts and replaced by weeds, open field, shrubs or grass savanna causing fragmentation of riparian forest with much less ecological value and economic potential. Generally, vegetation structure is concerned with distribution of individuals along the vertical and horizontal axes, as well as spatial arrangement of physiognomical, taxonomic, morphological and functional characteristics of the elements building the vegetation (Popma et al. 1988, Sterck \& Bongers,
2001). Various methods have been used to assess the structure of tropical forests (Whitmore, 1990), among which riparian forests are a major component. In the pre-forest zone of Côte d'Ivoire (West Africa), the physiognomy of riparian forests is very much similar to the one of dense semi-deciduous forest, with which they share similar features such as presence of buttresses, cauliflory, presence of numerous epiphytes and lianas (Devineau 1984). The floristic composition and plant community diversities of riparian forests in Omo have been studied, (Olatidoye, 2020) but an account of the general structure is lacking. The basal area, stem density and diameter class distribution are intrinsic characteristics of a given plant community, and are often used to compare vegetation types. This paper investigates the structural characteristics of riparian forests in Omo Biosphere Reserve, in terms of diameter class distribution, basal area and breast height.

\section{MATERIALS AND METHOD}

Description of Study Area: Omo Biosphere Reserve is an internationally recognised and unique habitat whose landscape has been partitioned as a result of biological population protection to meet up with the requirement of a typical biosphere reserve. It stretches North from latitudes $6^{0} 35^{1}$ to $7^{0} 05^{1} \mathrm{~N}$ and East $4^{0} 19^{1}$ 
to $4^{0} 40^{1} \mathrm{E}$ in Ijebu area of Ogun State, Southwestern Nigeria (Fig. 1). This study was carried out within the zonation of the reserve viz: The core (Strict Nature Reserve), the buffer zone and the transition zone within Omo Biosphere Reserve in Ogun State, Southwestern Nigeria.

The core zone covers about 460 hectares. The buffer zone surrounds the core area with an area of 8,165 hectares while the transition zone trans-borders the buffer zone and covers an area of 666,498.75 hectares. Each of these zones are separated by forest road, foot path, river streams or enclaves. Riparian areas within the biosphere consist of vegetation's along major rivers, streams and wetlands. Representative sites were chosen along the major river, streams and Upland in each of the core, buffer, and transition zone. Fig.1 shows the map of Omo Biosphere Reserve

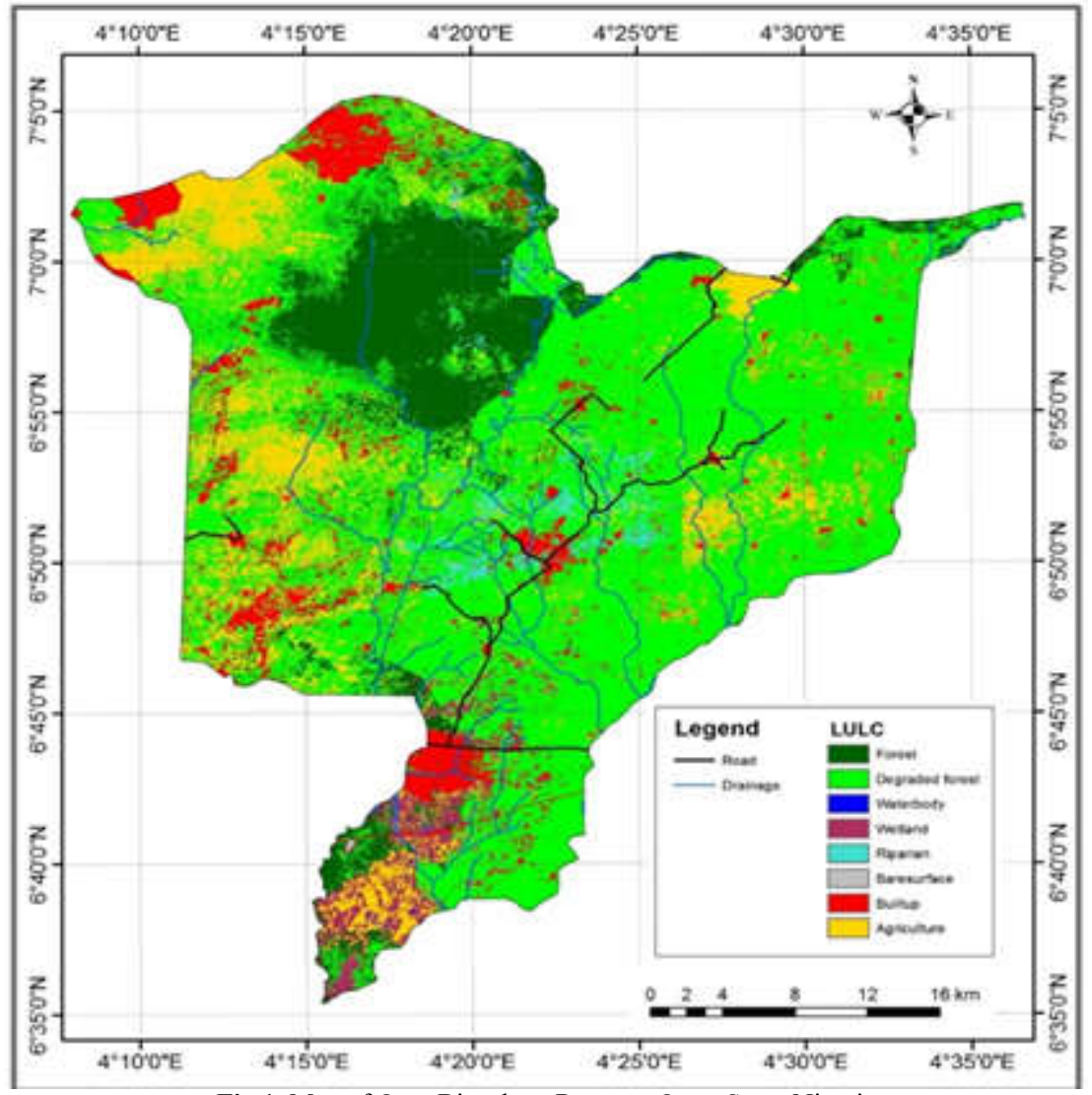

Fig 1: Map of Omo Biosphere Reserve, Ogun State, Nigeria

Data Collection: A total of 90 plots $(25 \mathrm{~m}$ by $25 \mathrm{~m})$ was selected for the study.

Thirty plots each was sampled along the riparian vegetation (core, buffer and transition) out of which 15 were sampled along the riparian forest and 15 plots for the adjacent upland vegetation in each zone. All the plant species within plots were identified, recorded.

The heights of trees were measured using an Haga Altimeter. The diameter at breast height of trees with a dbh of 10 and above $(d b h \geq 10)$ at $1.3 \mathrm{~m}$ above the ground were measured using a girthing tape and recorded to calculate estimates of timber volume and basal area. Analysis of variance was carried out for the variables.
Analysis of Data: Basal Area Calculation: Basal area of trees was calculated using the formula

$$
B A=\frac{\pi\left[D^{2}\right]}{4}
$$

Where $\mathrm{BA}=$ Basal area $\left(\mathrm{m}^{2}\right), \mathrm{D}=$ Diameter at breast height $(\mathrm{cm}) ; \Pi=$ Pie (3.142) measured in $\mathrm{m}^{2}$ per hectare

Volume Calculation and $V=e^{-8.433+2.33[\ln (D)]}$

Where $\mathrm{V}=$ Volume of tree $\left(\mathrm{m}^{3}\right)$ and $\mathrm{D}=$ diameter at breast height $(\mathrm{cm})$

\section{RESULTS AND DISCUSSION}

Analysis of Variance for Tree Variables, Basal Area and Volume per Hectare in the Zones: Analysis of variance for tree variables are shown in Table 1. This 
shows that there is significant difference in the diameter at breast height, height, volume and basal area respectively at 0.05 probability level. The mean basal area and mean volume for the Major River, Stream and Upland. Mean basal area per hectare for major river is $294,089.30 \mathrm{~cm}^{2} / \mathrm{ha}$, Stream 613.027 $\mathrm{cm}^{2} / \mathrm{ha}$, and Upland 205,648 $\mathrm{cm}^{2} / \mathrm{ha}$. While the mean volume per hectare for Major rivers, Stream and Upland were $8068.8 \mathrm{~m}^{3} / \mathrm{ha}, 8152 \mathrm{~m}^{3} /$ ha and 5240 $\mathrm{m}^{3} /$ ha respectively. (Table 2 ). Table 3 shows mean basal area and mean volume for the core, buffer and transition zones. Mean basal area for core is $507,399.50 \mathrm{~cm}^{2} /$ ha, buffer had $340,699 \mathrm{~cm}^{2} /$ ha and transition $264,656 \mathrm{~cm}^{2} / \mathrm{ha}$. While mean volume per hectare for Core is $7955.2 \mathrm{~m}^{3} / \mathrm{ha}$, buffer $7260 \mathrm{~m}^{3} / \mathrm{ha}$ and Transition $6254.4 \mathrm{~m}^{3} / \mathrm{ha}$. Table 4 shows minimum and maximum tree growth variables for diameter at breast height and height. Maximum dbh of $246 \mathrm{~cm}$ was obtained in the core and a minimum of $10 \mathrm{~cm}$ each within the zones while maximum height was observed in the core with $50.2 \mathrm{~m}$ and min height in the transition with $9.4 \mathrm{~m}$. Figure 1 and 2 also shows the total basal area was highest in the core and stream while total volume was also highest in the stream and core zones. Figure 3 and 4 shows that the diameter class size was highest in 10-19 class size for the Core zone and Major Rivers

Table 1: Analysis of Variance for Some Tree Variables

\begin{tabular}{|c|c|c|c|c|c|c|}
\hline Variables & & $\overline{\mathrm{Df}}$ & SS & MS & $\mathrm{F}$ & $\mathrm{P}$ \\
\hline \multirow[t]{3}{*}{$\mathrm{DBH}$} & Betw grps & 2 & 11181.2 & 5590.6 & $1.206^{*}$ & 0.304 \\
\hline & Witn grps & 6 & 403360 & 4636.3 & & \\
\hline & Total & 8 & 414542 & & & \\
\hline \multirow[t]{3}{*}{ Height } & Betw grps & 2 & 10034.5 & 82.4 & $1.041 *$ & 0.425 \\
\hline & Witn grps & 6 & 21645.8 & 58.9 & & \\
\hline & Total & 8 & 31680.3 & & & \\
\hline \multirow[t]{3}{*}{ Volume } & Betw grps & 2 & 1.0085 & 0.504 & $0.638^{*}$ & 0.03 \\
\hline & Witn grps & 6 & 0.4557 & 0.075 & & \\
\hline & Total & 8 & 1.4643 & & & \\
\hline \multirow[t]{3}{*}{ Basal Area } & Betw grps & 2 & 144.3 & 4.54 & $0.789 *$ & 0.496 \\
\hline & Witn grps & 6 & 456.2 & 1.24 & & \\
\hline & Total & 8 & 650.5 & & & \\
\hline
\end{tabular}

Table 2: Mean Basal Area and Mean Volume of the Major River, Stream and Upland

\begin{tabular}{llllll}
\hline & M. rivers & Stream & Upland & Riparian & Overall (90 plots) \\
\hline Mean. Basal. Area & $18,380.58$ & $38,314.22$ & 12,853 & $28,347.40$ & $23,182.60$ \\
\hline B.A / hect $\left(\mathrm{cm}^{2} / \mathrm{ha}\right)$ & $294,089.30$ & 613,027 & 205,648 & $453,558.40$ & $370,921.60$ \\
Mean. Vol $\left(\mathrm{m}^{3}\right)$ & 504.3 & 509.5 & 327.5 & 1700.5 & 1491 \\
Vol/hect $\left(\mathrm{m}^{3} / \mathrm{ha}\right)$ & 8068.8 & 8152 & 5240 & 27200 & 23,856 \\
\hline
\end{tabular}

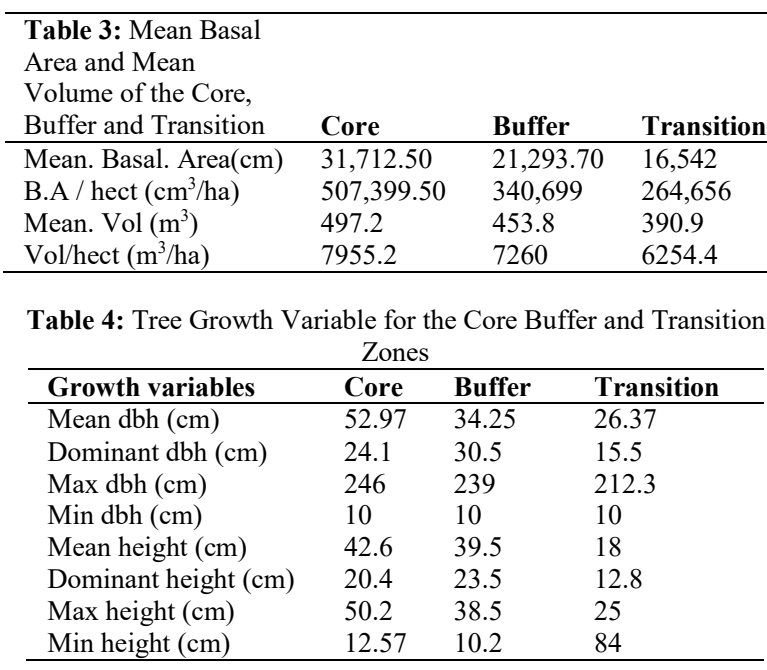

In all the study sites, a greater number of individuals were found in the lower diameter classes. Fifty percent of the individuals in the riparian forest of Omo were found in the $10-19.9 \mathrm{~cm}$ and $4.2 \%$ were found having above 100 .

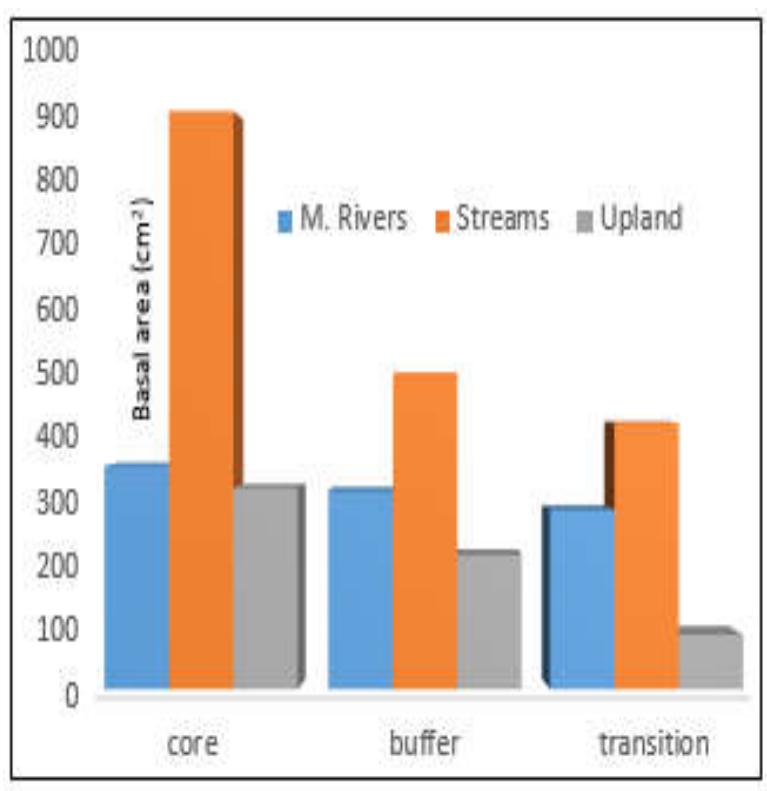

Fig. 1: Total basal Area for Major Rivers, Streams and Transition in the zones 


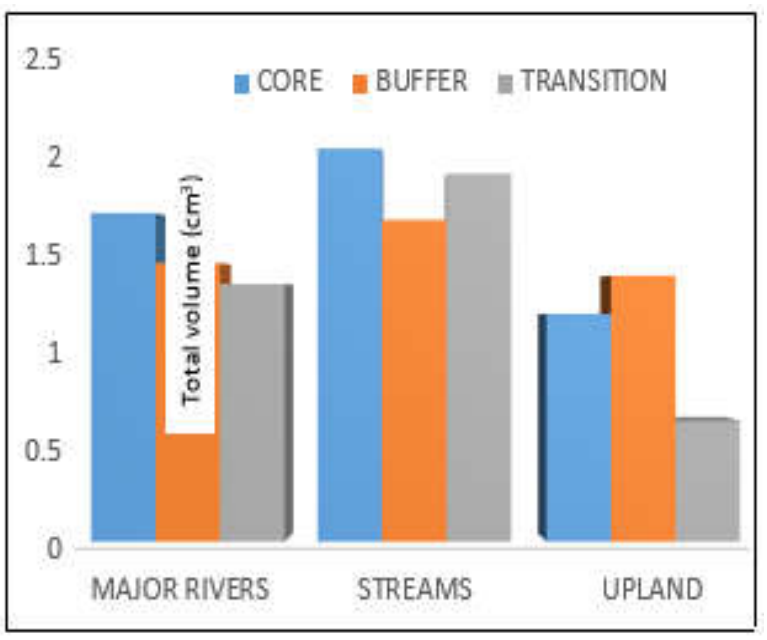

Fig. 2: Total Volume within Major River, Stream \& Upland in the three Zones

Table 5. Tree Diameter Distribution of the Riparian Zones

\begin{tabular}{llll}
\hline \multicolumn{3}{c}{ Number Of Trees In Each Diameter Class Range } \\
\hline Range & Core & Buffer & Transition \\
\hline $10-19.9$ & 206 & 158 & 141 \\
$20-29.9$ & 116 & 116 & 83 \\
$30-39.9$ & 53 & 66 & 55 \\
$40-49.9$ & 32 & 32 & 31 \\
$50-59.9$ & 20 & 24 & 7 \\
$60-69.9$ & 17 & 11 & 8 \\
$70-79.9$ & 6 & 3 & 5 \\
$80-89.9$ & 5 & 3 & 6 \\
$90-99.9$ & 4 & 3 & 1 \\
$>100$ & 9 & 7 & 5 \\
\hline
\end{tabular}

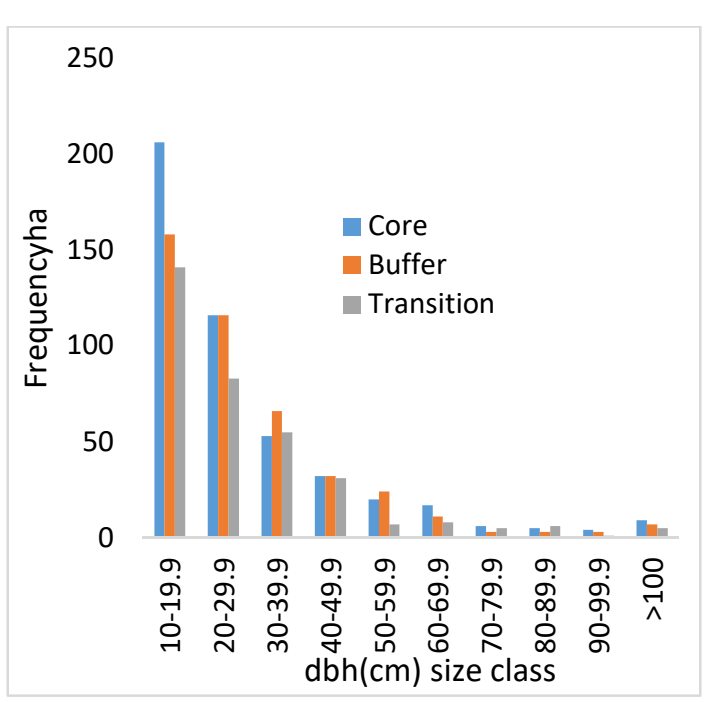

Fig. 3: Diameter Class Size for Core, Buffer and Transition Zone in Omo Biosphere Reserve

The number of individuals within the largest diameter class $\geq 100 \mathrm{~cm}$ ranged between $1.9 \%, 1.6 \%$ and $1.4 \%$ in the riparian forest of the Core, Buffer and Transition respectively. Akinyemi (2017) observed $54.7 \%$ of the individuals in the Omo forest to be in the dbh class of
10-19.9 $\mathrm{cm}$. In the riparian forest of Belize, similar result was also obtained where about $78 \%$ of trees were in the smallest dbh class $(10-20 \mathrm{~cm})$ (Meave and Kellman, 1994).

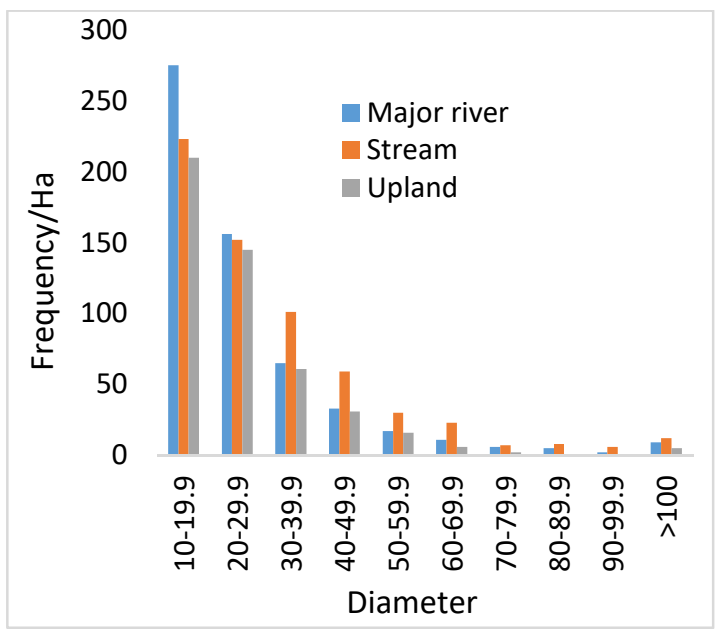

Fig. 4: Tree Diameter Class Size for the Major Rivers, Stream, Upland in Omo Biosphere

Hence the riparian forest of Omo Biosphere reserve can be characterized as an averagely high biomass community with numerous small stemmed trees and corresponding few large trees compared to the upland tropical forests. The pattern of the decreasing curve has a reverse-J distribution typical of a seed regenerating natural forest. The diameter class size indicates the general trends of population dynamics and recruitment processes of a given tree population (Adekunle and Olagoke, 2008). Nath et al. (2005) asserted that the inverted J-curve, where the abundance decreases with increasing diameter, is an indication of good regeneration of the constituent species. The conformity of the population structure of trees in all the selected forest reserves with this reverse J-shaped structure clearly reflects the regenerating potential of these forest reserves over time. As the larger population falls in the lower diameter size class, the amount of merchantable trees $(>48 \mathrm{~cm})$ is below average. Furthermore, the availability of large trees with dbh that is above $100 \mathrm{~cm}$ in all the zones could be due to the fact that there are conservation steps in the reserve, restricting uncontrolled felling or over exploitation of timber resources in the forest reserve.

Conclusion: There is high variation in the physiognomy of the riparian forest of Omo Biosphere Reserve. Tree stem diameter and height are averagely small. Few species contribute more to the total abundance and basal area with a high abundance of small and medium size trees, this implies the simplification of floristic and structural levels the 
riparian vegetation of Omo is presently facing. This necessitates actions to be taken to overcome treat to biodiversity by preventing over-exploitation and sustaining existing legal protection.

\section{REFERENCES}

Akinyemi, OD (2017). Population and Structure of Trees in Selected Lowland Rainforest Reserves in Southwestern Nigeria. Unpublished Ph.D. thesis University of Ibadan, Nigeria. March 2017

Adekunle, VAJ; Olagoke, AO (2007). Diversity and bio-volume of tree species in Natural Forest Ecosystem in bitumen-producing area of Ondo State, Nigeria: a baseline study. Biodiv. Conserv. 15(2): $50-63$

Devineau, JL (1984). Travaux des chercheurs de la station de Lamto: Structure et dynamique de quelques forêts tropophiles de l'Ouest Africain (Côte d'Ivoire). Programme MAB savanes no.5. Université d'Abidjan, Station d'Ecologie tropicale de Lamto, Côte d'Ivoire. 294p

Meave, J; Kellman, M (1994). Maintenance of rain forest diversity in riparian forests of tropical savannas: implications for species conservation during Pleistocene drought. J. Biogeogr. 21: 121135
Nath, PC; Aruuchalam, A; Khan, ML; Aruuchalam, K; Bharbuuiya, ARV (2005). Vegetation analysis and tree population structure of tropical wet evergreen forests in and around Nandapha Natural Park, North-east India. Biodiversity Conservation 14: $2109-2136$

Olatidoye, OR;Isichei, AO; Oyelowo, OJ; Kambai, C (2020). Assessment of riparian forest fragments tree diversity in Omo Biosphere Reserve, Ogun State, Nigeria. (Submitted to Ethiopian Journal of Science and Technology)

Popma, J; Boners, F; Meave, J (1988). Patterns in the vertical structue of the tropical lowland rainforest at Los Tuxtlas,Mexico. Vegetation 74: 81-91

Sterck, FJ; Bogers, F (2001). Crown development in tropical rain foests trees: patterns with tree height and light availability. J. Ecol. 89: 1-13

Wu, JG (2013). Key concepts and research topics in landscape ecology revisited: 30 years after the Allerton Park workshop. Landsc Ecol 28: 1-11.

Whitmore, TC (1990). An introduction to tropical rain forests. Clarendon Press, Oxford. 225p. 